\title{
Extreme Precipitation and Climate Gradients in Patagonia Revealed by High-Resolution Regional Atmospheric Climate Modeling
}

\author{
Jan T. M. Lenaerts, Michiel R. van den Broeke, Jan M. van Wessem, AND WiLlem Jan Van DE BerG
}

Institute for Marine and Atmospheric Research, Utrecht University, Utrecht, Netherlands

ERIK VAN MEIJGAARD AND LAMBERTUS H. VAN ULFT

Royal Netherlands Meteorological Institute, De Bilt, Netherlands

MARIUS SCHAEFER

University of Valdivia, Valdivia, Chile

(Manuscript received 24 September 2013, in final form 7 March 2014)

\begin{abstract}
This study uses output of a high-resolution $(5.5 \mathrm{~km})$ regional atmospheric climate model to describe the present-day (1979-2012) climate of Patagonia, with a particular focus on the surface mass balance (SMB) of the Patagonian ice fields. Through a comparison with available in situ observations, it is shown that the model is able to simulate the sharp climate gradients in western Patagonia. The southern Andes are an efficient barrier for the prevalent atmospheric flow, generating strong orographic uplift and precipitation throughout the entire year. The model suggests extreme orographic precipitation west of the Andes divide, with annual precipitation rates of $>5$ to $34 \mathrm{~m}$ w.e. (water equivalent), and a clear rain shadow east of the divide. These modeled precipitation rates are supported qualitatively by available precipitation stations and SMB estimates on the ice fields derived from firn cores. For the period 1979-2012, a slight atmospheric cooling at upper ice field elevations is found, leading to a small but insignificant increase in the ice field SMB.
\end{abstract}

\section{Introduction}

The Patagonian ice fields are the largest bodies of ice on the Southern Hemisphere outside Antarctica (Rignot et al. 2003). The Southern Patagonian Ice Field (SPI) comprises an area of approximately $13000 \mathrm{~km}^{2}$, whereas the Northern Patagonian Ice Field (NPI) is about one-fourth of that size $\left(4200 \mathrm{~km}^{2}\right)$. Outside these large ice fields, smaller ice-covered areas exist, mainly at latitudes south of $50^{\circ} \mathrm{S}$, such as the Cordillera Darwin ice field (Rivera et al. 2002). Recent studies, based on differential digital elevation models (DEMs) (Rignot et al. 2003; Willis et al. 2012) and gravimetric observations from the Gravity Recovery and Climate Experiment (GRACE) satellites (Chen et al. 2007; Gardner et al. 2013), have found that the SPI and NPI have been losing mass at a rate of $15 \pm 1 \mathrm{Gt} \mathrm{yr}^{-1}$ from 1975 to 2000 ,

Corresponding author address: Jan T. M. Lenaerts, Princetonplein 5, Princetonplein 5, Utrecht, 3584 CC, Netherlands. E-mail: jtmlenaerts@gmail.com increasing to $24 \pm 1 \mathrm{Gt} \mathrm{yr}^{-1}$ from 2000 to 2012 (Willis et al. 2012), adding significantly to current global mean sea level rise. Dating of ice field moraines has indicated that twentieth-century glacier retreat rate was an order of magnitude larger than the long-term steady retreat since the Last Glacial Maximum (Glasser et al. 2011).

Glaciers gain mass through accumulation (snow and rain) and lose mass at the surface by runoff, snow sublimation, and erosion, and by calving if they terminate in oceans or lakes. In the absence of significant melt, and with sublimation-erosion of snow an estimated order of magnitude smaller, the SMB in the cold upper zones of the ice fields is largely determined by snowfall (Escobar et al. 1992; Shiraiwa et al. 2002). Their outlet glaciers have steep slopes and end at low elevations, where high melt rates are observed, of up to $\sim 15 \mathrm{~m}$ w.e. (water equivalent) per year (Naruse et al. 1997). Moreover, many of these glaciers terminate in fjords; their calving regime is therefore tidewater-controlled and sensitive to ocean temperatures (Warren and Sugden 1993). This implies that the ice fields strongly depend on atmospheric 
and oceanic conditions; the recent ice field demise corresponds to a near-surface temperature increase (Rosenblüth et al. 1997) and atmospheric warming at $850 \mathrm{hPa}$ of $\sim(0.5-1.0) \mathrm{K}$ in the last $50 \mathrm{yr}$ (Rasmussen et al. 2007).

However, it is unclear which mechanisms drive the recent mass loss. In particular, the surface mass balance [SMB; the balance between surface mass gains (precipitation) and losses (surface runoff, snow sublimation, and erosion)] is poorly constrained. Because of their remoteness and harsh climate, observations of SMB on the ice fields are scarce and sometimes difficult to interpret; the few measurements indicate locally extremely high annual SMB of $>5$ to $15 \mathrm{~m}$ w.e. (Matsuoka and Naruse 1999; Schwikowski et al. 2013), significantly more than most other glaciated regions on earth.

These extreme precipitation amounts are generated through orographic uplift of humid air masses when the prevalent zonal atmospheric flow encounters the high $(>2 \mathrm{~km})$ southern Andes mountain range (Schneider et al. 2003; Smith and Evans 2007; Garreaud et al. 2013). This narrow mountain range $[\sim(50-100) \mathrm{km}]$ is poorly resolved in low-resolution general circulation models (GCMs) and atmospheric reanalysis products; with a typical horizontal resolution of 50-200 km, they do not fully capture these high precipitation amounts. Recently, higher-resolution $(\sim 25 \mathrm{~km})$ gridded datasets of precipitation have been generated (e.g., Huffman et al. 2009), based on satellite microwave data, but these heavily depend on the availability of reliable in situ observations for bias correction. In all of southern Patagonia, only one such station covering the full postsatellite era is available, and this station is situated along the Chilean coast (Garreaud et al. 2013). High-resolution atmospheric modeling is a useful tool to better resolve the extreme climate gradients in Patagonia (Garreaud et al. 2013), but usually the length of the simulations is short owing to high computational expenses (Schaefer et al. 2013).

Here we describe the climate of Patagonia, with particular focus on the climate on and around the ice fields, using the results from a high-resolution $(\sim 5.5 \mathrm{~km})$ regional atmospheric climate model, applied to Patagonia and driven by the European Centre for Medium-Range Weather Forecasts (ECMWF) Interim Re-Analysis (ERA-Interim) for the satellite era, up to the present (1979-2012). After a description of the regional climate model and available observational data (section 2), we describe the simulated large-scale circulation, nearsurface climate, and precipitation climatology and compare it to observations (section 3). Section 4 contains a discussion of the results and conclusions.

\section{Data}

\section{a. Regional atmospheric climate model}

In this study, we use the Regional Atmospheric Climate Model (RACMO), version 2.3 (RACMO2 hereafter). The model has a horizontal resolution of $\sim 5.5 \mathrm{~km}$ and 40 sigma levels in the vertical, which follow the topography close to the surface but approximate pressure levels at greater heights in the atmosphere. The description of the physical processes is adapted from the ECMWF Integrated Forecast System (IFS), and is recently updated from cycle 23r4 (White 2001) to cycle 33r1 (ECMWF-IFS 2008). This update consists, among others, of the inclusion of a parameterization of ice supersaturation in clouds, improved transition between cloud vapor and precipitation in convective clouds, and implementation of more sophisticated shortwave radiation, cloud-radiation interactions, and boundary layer schemes (ECMWF-IFS 2008; Van Wessem et al. 2014). The effect of form drag, which depends on subgrid-scale orography (Beljaars et al. 2004), has been switched off because it appears to lead to a strong underestimation of near-surface wind speeds in mountainous areas.

In recent years, RACMO2 physics have also been updated to improve simulation of ice-sheet climate. In particular, RACMO2 includes a single-column, multilevel snow scheme (Ettema et al. 2010), which partitions available liquid water from surface melt into refreezing, percolation, and runoff. Moreover, surface albedo of snow is made a function of snow grain size, which is calculated prognostically (Kuipers Munneke et al. 2011). Drifting snow sublimation and redistribution/ erosion, which have a marked effect on the SMB in windy areas of the ice sheets, are included as well (Lenaerts et al. 2012a). The above adaptations to the model physics have improved RACMO2's (version 2.1) performance in simulating the climate and SMB of Greenland (Van Angelen et al. 2012), Arctic Canada (Lenaerts et al. 2013), and Antarctica (Lenaerts and Van den Broeke 2012; Lenaerts et al. 2012b). More recently, Van Wessem et al. (2014) have shown that the update from version 2.1 to 2.3 reduces the cold bias in near-surface temperature due to a better representation of the longwave downward radiative flux.

Because of the smaller surface area of the Patagonian ice masses relative to the large ice sheets, and to properly represent the steep topography of the southern Andes, we applied RACMO2 to this region with a high horizontal resolution of $\sim 5.5 \mathrm{~km}$. As shown in previous work (e.g., Mass et al. 2002), this resolution is required to simulate realistic patterns and amounts of orographic precipitation. On the other hand, this resolution is still 


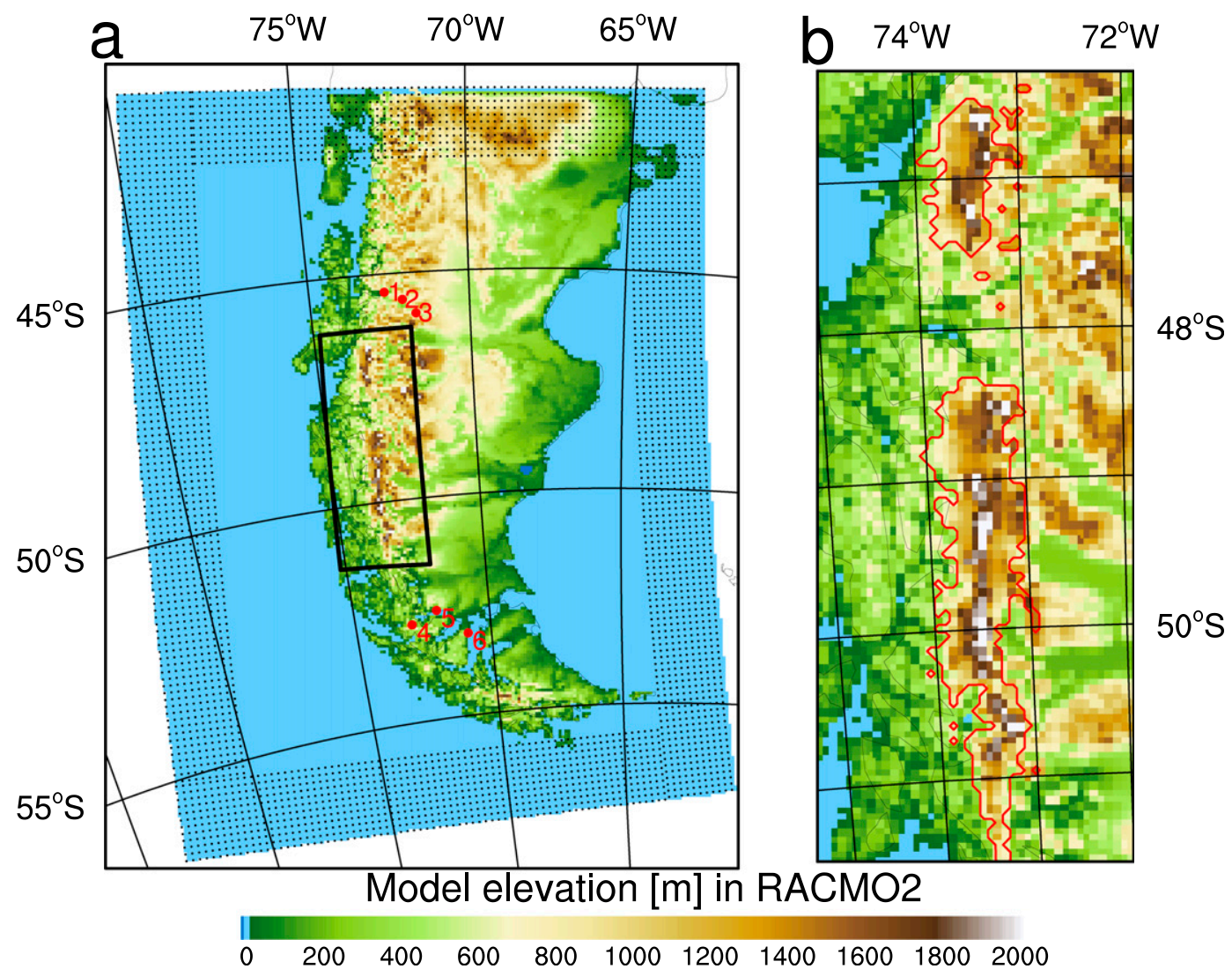

FIG. 1. (a) Model elevation in domain with relaxation zone illustrated by the black stippling. (b) Zoom of ice fields showing the RACMO2 elevation (colors) and the delineation of the ice fields in the model grid (red contour). The subdomain is indicated by the black rectangle in (a). Locations of stations with temperature data shown in Figs. 4 and 5 and Table 3 are indicated in red $(1=$ AYSE, $2=$ COYH, $3=$ BALM, $4=$ NPBA, $5=$ SKYR, and $6=$ PUNT; see Table 1 for expansions of station names).

coarser than the typical size of local atmospheric processes such as thunderstorms, which justifies the use of a hydrostatic model for this study. Moreover, such phenomena rarely occur in Patagonia, where the weather is mainly driven by the large-scale atmospheric circulation. The model domain (Fig. 1) ranges from the South Pacific at $\sim 80^{\circ} \mathrm{W}$ in the west to the western side of the Falkland Islands in the Atlantic Ocean in the east, and from northern Patagonia $\left(41^{\circ} \mathrm{S}\right)$ to the Drake Passage, south of Chile $\left(\sim 57^{\circ} \mathrm{S}\right)$. The lateral boundaries of the domain are chosen such that they are located on the ocean, or, when over land, do not cross distinct topography (Fig. 1). Since most of the weather systems affecting Patagonia are advected from the west, the western domain boundary is located $\sim 300 \mathrm{~km}$ from the Chilean coast.

At the model boundaries, and each $6 \mathrm{~h}$, vertical temperature, humidity, and wind profiles from the ERAInterim reanalysis (1979-present; Dee et al. 2011) are relaxed toward RACMO2 resolution. To ensure a proper downscaling from ERA-Interim ( $\sim 80-\mathrm{km}$ resolution) to RACMO2 in the relaxation zone, we set its width to 32 RACMO2 grid points (i.e., $\sim 180 \mathrm{~km}$ ). Sea surface temperature from ERA-Interim is prescribed at each RACMO2 ocean grid point. The atmosphere and land-snow surface in the inner RACMO2 domain are allowed to evolve freely. The ice mask definition originates from ECOCLIMAP (Champeaux et al. 2005); model topography is constructed by weighted interpolation of the 90-m resolution Shuttle Radar Topography Mission (SRTM) data (Reuter et al. 2007; available online at http://srtm.csi.cgiar.org) to RACMO2 grid resolution.

The model is first initialized with a cold, thick, isothermal and dry snowpack. We use $16 \mathrm{yr}$ of model simulation (1979-95) to spin up the snowpack, and to allow the formation of ablation and accumulation areas on the ice fields. For the final simulation, we initialized the snowpack on 1 January 1979 with final snowpack data of this first simulation. 
TABLE 1. List of available weather stations used in this study for model evaluation. Shown are the abbreviated and long name, latitude and longitude, station elevation in meters above sea level, available time period, available variables $(\mathrm{PR}=$ precipitation; $T=$ temperature; and $U=$ wind speed). S2003 refers to Schneider et al. (2003).

\begin{tabular}{|c|c|c|c|c|c|c|c|}
\hline Short name & Long name & Lat $\left({ }^{\circ} \mathrm{S}\right)$ & Lon $\left({ }^{\circ} \mathrm{W}\right)$ & Elev (m ) & Period & Variables & Source \\
\hline CHAC & Chacabuco & $45^{\circ} 26^{\prime}$ & $72^{\circ} 49^{\prime}$ & 20 & 1950-2007 & PR & DGA \\
\hline RIPS & Rio Puenta Nueva & $49^{\circ} 6^{\prime}$ & $74^{\circ} 24^{\prime}$ & 10 & 1950-2007 & PR & DGA \\
\hline RIPA & Rio Puesca & $48^{\circ} 9^{\prime}$ & $73^{\circ} 5^{\prime}$ & 20 & 1950-2007 & PR & DGA \\
\hline RIBA & Rio Baker & $47^{\circ} 8^{\prime}$ & $72^{\circ} 43^{\prime}$ & 160 & $1950-2007$ & PR & DGA \\
\hline PUED & Puerto Eden & $49^{\circ} 7^{\prime}$ & $74^{\circ} 24^{\prime}$ & 10 & 1950-2007 & PR & DGA \\
\hline LADI & Lago Dickson & $50^{\circ} 49^{\prime}$ & $73^{\circ} 6^{\prime}$ & 200 & 1950-2007 & PR & DGA \\
\hline TORT & Tortel & $47^{\circ} 47^{\prime}$ & $73^{\circ} 32^{\prime}$ & 10 & 1950-2007 & PR & DGA \\
\hline BAMU & Bahia Muerta & $46^{\circ} 27^{\prime}$ & $72^{\circ} 40^{\prime}$ & 240 & 1950-2007 & PR & DGA \\
\hline AYSW & Aysen & $45^{\circ} 24^{\prime}$ & $72^{\circ} 40^{\prime}$ & 11 & 1950-2007 & $\mathrm{PR}, T, U$ & DMC \\
\hline BALM & Balmaceda & $45^{\circ} 54^{\prime}$ & $71^{\circ} 43^{\prime}$ & 520 & 1950-2007 & $\mathrm{PR}, T$ & $\mathrm{DMC}$ \\
\hline $\mathrm{CHIC}$ & Chico & $46^{\circ} 32^{\prime}$ & $71^{\circ} 41^{\prime}$ & 327 & 1950-2007 & $\mathrm{PR}, T$ & DMC \\
\hline $\mathrm{COYH}$ & Coyhaique & $45^{\circ} 35^{\prime}$ & $72^{\circ} 7^{\prime}$ & 310 & $1950-2007$ & $\mathrm{PR}, T$ & $\mathrm{DMC}$ \\
\hline NPBA & Gran Campo NPB & $52^{\circ} 48^{\prime}$ & $72^{\circ} 56^{\prime}$ & 26 & $2000-12$ & $\mathrm{PR}, T, U$ & S2003 \\
\hline PASO & Paso Galeria & $52^{\circ} 45^{\prime}$ & $73^{\circ} 1^{\prime}$ & 383 & $2000-12$ & $\mathrm{PR}, T$ & S2003 \\
\hline SKYR & Skyring & $52^{\circ} 33^{\prime}$ & $71^{\circ} 58^{\prime}$ & 8 & $2000-12$ & $\mathrm{PR}, T, U$ & S2003 \\
\hline PUNT & Punto Arenas & $53^{\circ} 8^{\prime}$ & $70^{\circ} 53^{\prime}$ & 6 & $2000-11$ & $\mathrm{PR}, T, U$ & S2003 \\
\hline
\end{tabular}

\section{b. Observations}

\section{1) WEATHER STATIONS}

Because of its relative remoteness and adverse weather conditions, only very few reliable weather station data are available. For this study, we compiled a dataset of 16 weather stations from all of western Patagonia (Table 1) that provide a quasi-continuous and multiple-year record of precipitation amount (PR), near-surface temperature $(T)$ and/or wind speed and direction $(U)$. The first eight stations in Table 1 (CHAC through BAMU), managed by the Chilean Water Directorate (DGA), are located along major Chilean rivers or lakes. Stations AYSE through COYH are from the Chilean Weather Service (DMC), and stations NPBA through PUNT are introduced in Schneider et al. (2003).

Precipitation is measured with tipping-gauge rain buckets, which are usually unshielded and placed at $1 \mathrm{~m}$ above the surface. Rainfall may be underestimated because of deformation of the wind field, but may also be overestimated in stormy weather through vibrations of the gauge (Schneider et al. 2003). Measurement uncertainty is generally assumed to be $20 \%$, but measurements were not corrected since no calibration procedure was available for this specific instrument. To account for this uncertainty in the measurements, we have included a $20 \%$ uncertainty in the gauge-derived precipitation. Temperature and wind speed-direction are measured at 2-m height. The DMC stations only provide daily maximum and minimum temperatures, whereas we use daily mean temperature for the NPBA-PUNT stations. To compare wind data with model output (which is representative for $10-\mathrm{m}$ height), we extrapolated the observed wind speed to $10 \mathrm{~m}$ assuming a logarithmic wind profile and simulated mean $z_{0}$. For each of the stations we only used the temporally overlapping data in the comparison between model and observations. For the DGA stations, that implies that we did not use data from the period $1950-78$ in this study.

\section{2) FIRN CORES}

On the ice fields, a thick winter snowpack, strong winds, and wet conditions throughout the year prevent the operation of automatic weather stations. At present, we are therefore unable to evaluate the model climate above snow and ice in any detail. Instead, we evaluate modeled SMB through a comparison with SMB estimates that originate from firn cores or annual readings of mass balance stakes. Table 2 shows the eight point measurements of SMB that were found in the literature. These observations are all located in the accumulation zones or near the equilibrium line of outlet glaciers of the NPI and SPI. Long-term observations in the ablation zone are absent, but some short-term measurements were performed on the outlet of San Rafael Glacier (NPI); here, more than $1.5 \mathrm{~m}$ w.e. of melt was observed near the glacier terminus [at $120 \mathrm{~m}$ above mean sea level (MSL)] in less than one month (Ohata 1985; Schaefer et al. 2013). Since the observational time span (Table 2) is only known by approximation, we are unable to select the same time periods in RACMO2. Therefore we choose to compare the observed SMB with the longterm (1979-2012) mean SMB of RACMO2 and included the 1979-2012 interannual variability (one standard deviation) as a measure of uncertainty. 
TABLE 2. List of available SMB data on the NPI (first two rows) and SPI (last five rows). The RACMO2 SMB for each location is also given along with the standard deviation of the 1979-2012 annual SMB.

\begin{tabular}{|c|c|c|c|c|c|c|c|}
\hline \multirow[b]{2}{*}{ Location } & \multirow{2}{*}{$\begin{array}{c}\text { Latitude } \\
\left({ }^{\circ} \mathrm{S}\right)\end{array}$} & \multirow{2}{*}{$\begin{array}{c}\text { Longitude } \\
\left({ }^{\circ} \mathrm{W}\right)\end{array}$} & \multirow{2}{*}{$\begin{array}{c}\text { Elev } \\
\text { (m MSL) }\end{array}$} & $\begin{array}{c}\text { SMB } \\
\text { obs }\end{array}$ & $\begin{array}{c}\text { SMB } \\
\text { RACMO2 }\end{array}$ & \multirow{2}{*}{$\begin{array}{c}\text { Period } \\
\text { years }\end{array}$} & \multirow[b]{2}{*}{ Source } \\
\hline & & & & \multicolumn{2}{|c|}{$\mathrm{m}$ w.e. $\mathrm{yr}^{-1}$} & & \\
\hline San Rafael & $46^{\circ} 44^{\prime}$ & $73^{\circ} 32^{\prime}$ & 1296 & 3.45 & $3.33 \pm 4.08$ & 1984 & Yamada (1987) \\
\hline Nef & $46^{\circ} 56^{\prime}$ & $73^{\circ} 19^{\prime}$ & 1500 & 2.20 & $-3.88 \pm 5.60$ & 1996 & Matsuoka and Naruse (1999) \\
\hline Cerro Gorra Blanca & $49^{\circ} 8^{\prime}$ & $73^{\circ} 3^{\prime}$ & 2300 & 1.00 & $1.87 \pm 2.21$ & 1995-2001 & Schwikowski et al. (2003) \\
\hline Chico & $49^{\circ} 11^{\prime}$ & $73^{\circ} 11^{\prime}$ & 1444 & 0.57 & $-0.24 \pm 2.54$ & 1994-2001 & Rivera (2004) \\
\hline De Los Tres & $49^{\circ} 16^{\prime}$ & $73^{\circ}$ & 1475 & 0.07 & $0.35 \pm 0.80$ & $1995-96$ & Popovnin et al. (1999) \\
\hline Moreno B & $50^{\circ} 38^{\prime}$ & $73^{\circ} 15^{\prime}$ & 2680 & 1.20 & $11.05 \pm 4.17$ & $1980-85$ & Aristarain and Delmas (1993) \\
\hline Tyndall & $50^{\circ} 59^{\prime}$ & $73^{\circ} 31^{\prime}$ & 1756 & 15.40 & $13.94 \pm 5.78$ & 1998-2000 & Shiraiwa et al. (2002) \\
\hline Pio XI & $49^{\circ} 17^{\prime}$ & $73^{\circ} 21^{\prime}$ & 2600 & 5.80 & $6.25 \pm 2.84$ & 2000-06 & Schwikowski et al. (2013) \\
\hline
\end{tabular}

\section{Results}

\section{a. Large-scale circulation}

Patagonia is located between the high pressure ridge under the sinking southern branch of the Hadley circulation at $\sim 30^{\circ} \mathrm{S}$ and the circumpolar band of low pressure around Antarctica at $\sim 60^{\circ} \mathrm{S}$. The large pressure gradients between these two regions generate a strong upper-air westerly jet that is, in the absence of large topographic disturbances, less disturbed by topography and more unidirectional than in the Northern Hemisphere (Hobbs et al. 1998) and that exhibits less seasonal variability (Trenberth 1991). Figure 2 shows the large-scale circulation in southern Patagonia at $700 \mathrm{hPa}$. This pressure level is situated at an elevation of $\sim 3000 \mathrm{~m}$ above MSL, equivalent to the highest mountain peaks. It shows that the mean flow is strongly zonal, with a slight northern component in southern Patagonia. Highest onshore wind speeds are found in the latitudinal band $50^{\circ}-55^{\circ} \mathrm{S}$, where the meridional pressure gradients are largest, and in the winter season (Fig. 2). The flow slows down in front of, and is accelerated in the lee of, the highest topography; these patterns of flow convergence and divergence induce
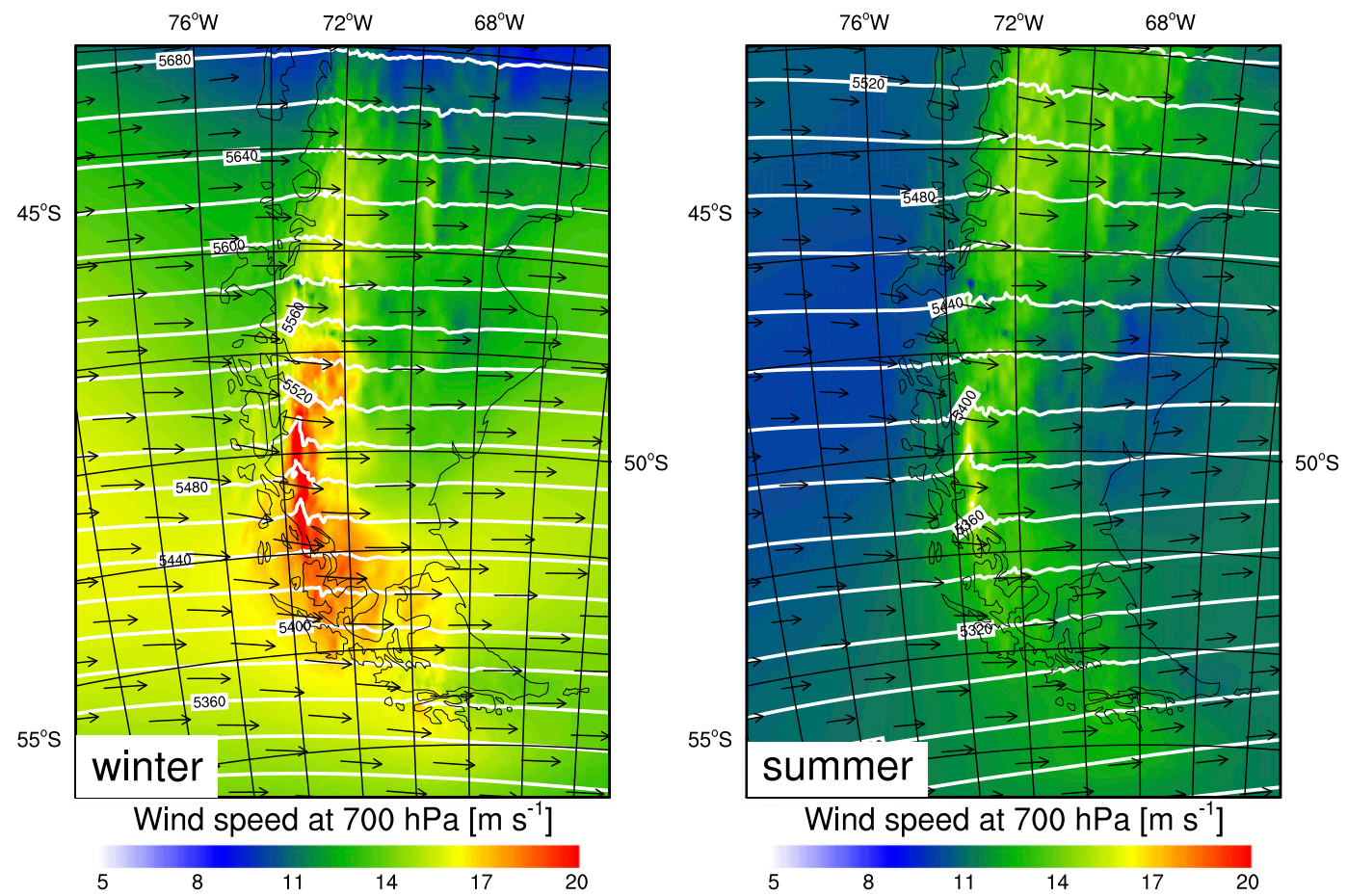

FIG. 2. Simulated (left) winter (June-August) and (right) summer (December-February) wind speed (colors), direction (arrows), and geopotential height (white lines, dam) at $700 \mathrm{hPa}$. 

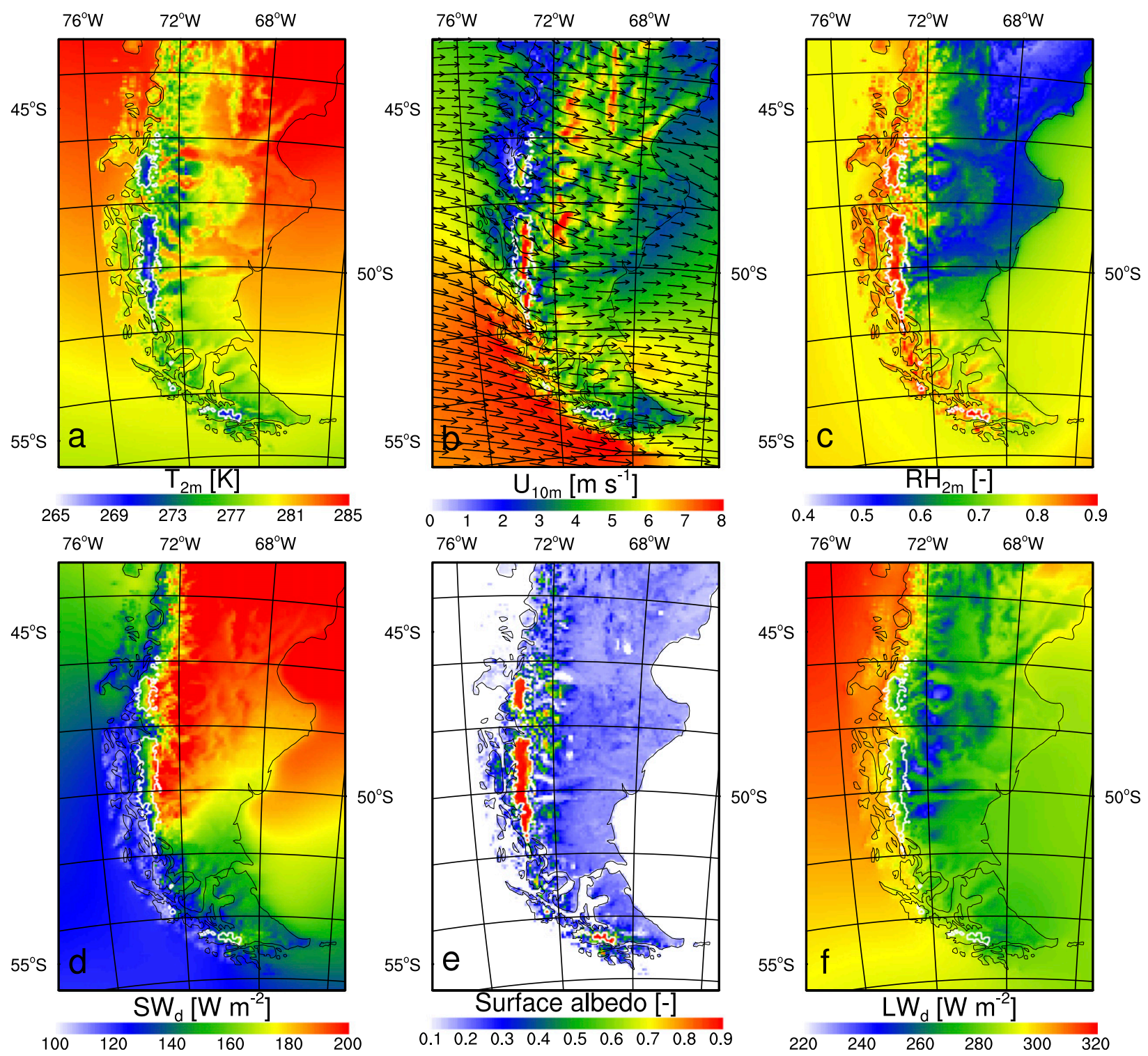

FIG. 3. Simulated annual mean (1979-2012) near-surface climate: (a) 2-m temperature (K); (b) 10-m wind speed (m s ${ }^{-1}$ ); (c) 2-m relative humidity; (d) downward shortwave radiation $\left(\mathrm{W} \mathrm{m}^{-2}\right)$; (e) surface albedo; and (f) downward longwave radiation ( $\left.\mathrm{W} \mathrm{m}^{-2}\right)$. The ice field boundaries are delineated in white.

changes in the geostrophic field, even at $700 \mathrm{hPa}$, indicated by the white lines that are bent above the highest topography.

\section{b. Near-surface climate}

Figure 3 shows the simulated annual mean nearsurface climate in RACMO2 (1979-2012). Nearsurface temperature (Fig. 3a) over the ocean ranges from $285 \mathrm{~K}$ in the north to $275 \mathrm{~K}$ in the south. Over the continent, near-surface temperature shows a strong imprint of elevation; we find the lowest temperatures on the ice fields $(<270 \mathrm{~K})$, and on the high plateau regions east of the Andes, which are snow-covered for a large part of the year. Highest temperatures are found in the dry, low-lying steppe regions of eastern Argentina. The near-surface wind field broadly follows the large-scale wind field (Fig. 2b); however, we also find strong $\left(>8 \mathrm{~m} \mathrm{~s}^{-1}\right)$ near-surface winds east of the Andes, where the nonvegetated surface and flat topography result in low surface roughness. Another prominent feature is the signature of downslope flow acceleration on the eastern side of the ice fields and, farther east, in the escarpment zone between the high plateaus and the low-lying desert (e.g., at $49^{\circ} \mathrm{S}, 71^{\circ} \mathrm{W}$ ). The large climate gradient between 

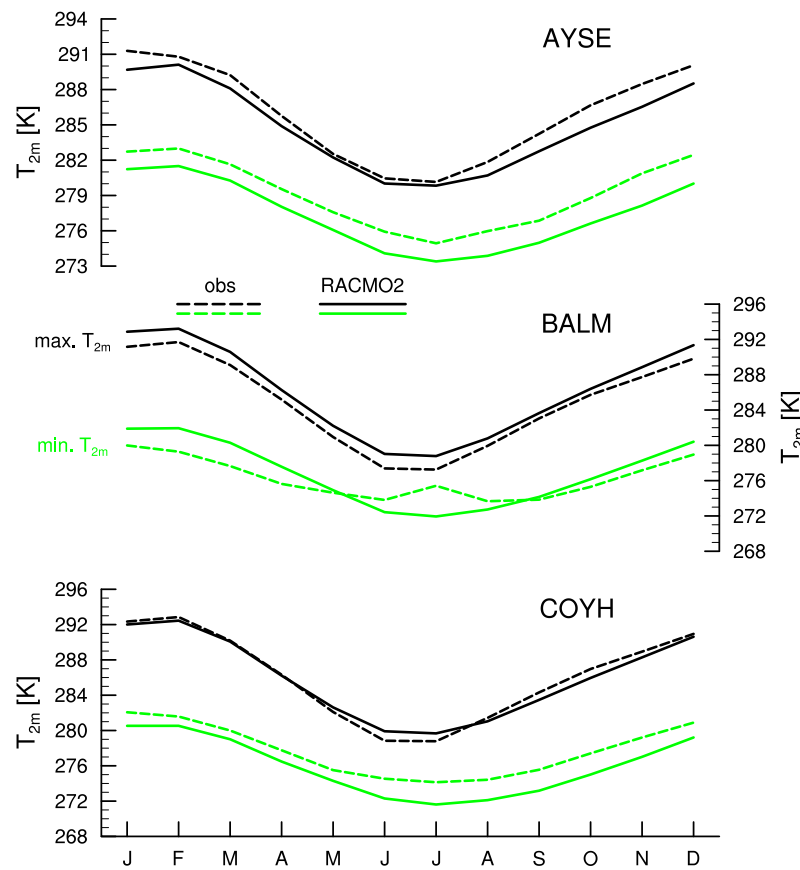

FIG. 4. Monthly mean daily maximum (black) and minimum (green) temperatures measured (solid lines) at AYSE, BALM, and COYH (stations 1-3 in Fig. 1) and simulated by RACMO2 at the closest grid point (dashed lines).

the wet west and much drier east is manifested in the relative humidity near the surface (Fig. 3c), with values $>90 \%$ along the western coastal regions and Andes range, decreasing rapidly to the east, where values lower than $60 \%$ are widespread. Shortwave downward radiation (Fig. 3d) is low in the wet regions $\left(<150 \mathrm{~W} \mathrm{~m}^{-2}\right)$, where cloud cover is abundant, and rises to more than $200 \mathrm{~W} \mathrm{~m}^{-2}$ in regions with less cloud cover. This implies that in the ice and snow-covered areas east of the topographical divide, abundant shortwave energy is available for melt. The amount of incoming longwave radiation $\left(\mathrm{LW}_{d}\right.$; Fig. $\left.3 \mathrm{f}\right)$ shows the opposite signal; in areas with high cloud cover, $\mathrm{LW}_{d}$ exceeds $300 \mathrm{~W} \mathrm{~m}^{-2}$, whereas the lowest $\mathrm{LW}_{d}$ values are found in the high, cloud-free plateau areas east of the Andes.

Figure 4 compares the mean seasonal cycle of modeled and observed near-surface temperatures at three DMC weather stations (Table 1) where long-term reliable measurements are available. Aysen (AYSE) is located $\sim 150 \mathrm{~km}$ inland, next to a fjord, at an elevation close to sea level. The amplitudes of the daily and seasonal cycle are relatively small due to the proximity of water. Here, daily maximum temperatures vary from $282 \mathrm{~K}$ in winter to $291 \mathrm{~K}$ in summer; daily minima vary from 275 to $282 \mathrm{~K}$. Coyhaique $(\mathrm{COYH})$ and Balmecida (BALM) are stations farther inland $(\sim 250 \mathrm{~km})$, where
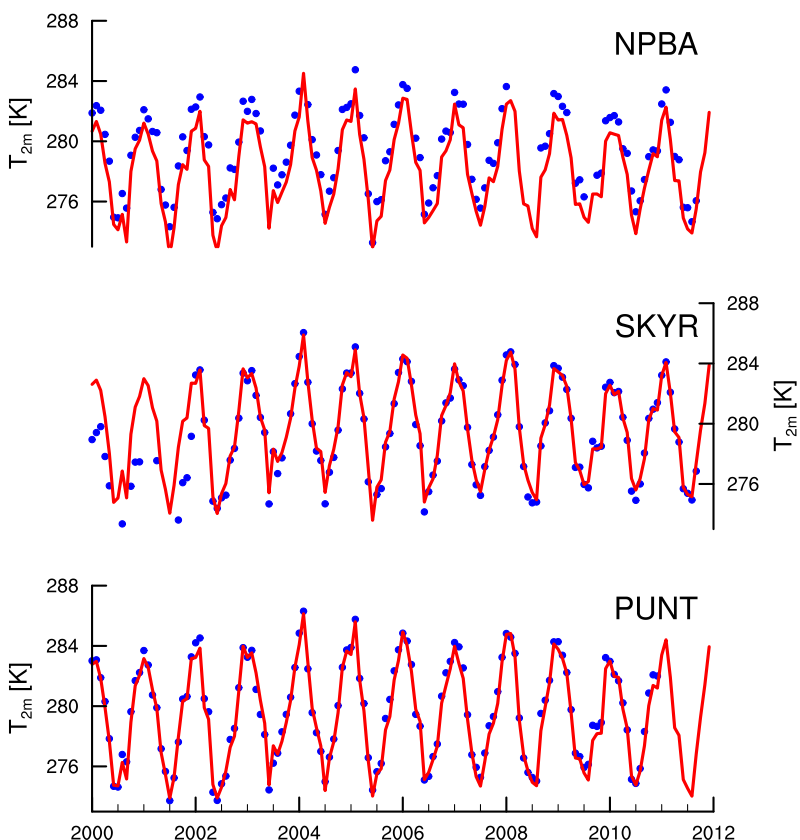

FIG. 5. Monthly mean temperature from AWS observations (blue) at NPBA, SKYR, and PUNT (see Table 1) and from the closest grid point in RACMO2 (red) for the period 2000-11.

precipitation rates are lower, clouds less prominent, and daily and seasonal temperature ranges larger by $\sim(2-3) \mathrm{K}$ than at the coast; summer maxima are higher and winter minima are lower. The seasonal and daily temperature cycles at these three stations are relatively well simulated by RACMO2 and mostly fall within the uncertainty of the measurements $(\sim 1 \mathrm{~K})$. Annual mean temperature, defined simply as the arithmetic average between maximum and minimum temperature, is somewhat overestimated at BALM (mean bias of $+0.8 \mathrm{~K})$ and underestimated in AYSE $(-1.5 \mathrm{~K})$ and COYH $(-1.0 \mathrm{~K})$.

To analyze the model's ability to simulate interannual variability of temperature, we compare monthly mean simulated temperatures with automatic weather station (AWS) records from southern Patagonia $\left(\sim 53^{\circ} \mathrm{S}\right.$; Schneider et al. 2003; Fig. 1). These stations are located in a region with large zonal climate gradients, with NPBA and SKYR situated in the wet region west of the Andes range, and PUNT farther east in a much drier climate. Figure 5 shows that RACMO2 captures the interannual temperature variations well at NPBA (correlation coefficient $r=0.99$ and mean bias of $-1.2 \mathrm{~K}$ ), at SKYR $(r=0.93$, bias $=+0.5 \mathrm{~K})$, and at PUNT $(r=0.99$, bias $-0.2 \mathrm{~K}$ ). Also, the summers 2004/05 and 2005/06 were the warmest in the time series, both in the observations and in RACMO2. 
TABLE 3. Seasonal variability of near-surface temperature (K) according to the observations (first column for each season) and RACMO2 minus observations (second column for each season) at the stations shown in Figs. 4 and 5. Autumn is the months MarchMay (MAM), winter months are June-August (JJA), spring months are September-November (SON), and summer months are December-February (DJF). The mean temperature at stations AYSE, BALM, and COYH is approximated by taking the arithmetic average of minimum and maximum daily temperature.

\begin{tabular}{|c|c|c|c|c|c|c|c|c|}
\hline Season & \multicolumn{2}{|c|}{ Autumn } & \multicolumn{2}{|c|}{ Winter } & \multicolumn{2}{|c|}{ Spring } & \multicolumn{2}{|c|}{ Summer } \\
\hline \multicolumn{9}{|l|}{ Station } \\
\hline \multicolumn{9}{|c|}{ Northern array (Fig. 4) } \\
\hline AYSE & 282.7 & -1.1 & 278.2 & -1.2 & 282.6 & -2.0 & 286.9 & -1 \\
\hline BALM & 280.5 & 1.5 & 276.2 & -0.3 & 280.5 & 0.8 & 285.5 & 1 \\
\hline $\mathrm{COYH}$ & 282.0 & -0.5 & 277.0 & -0.4 & 282.1 & -1.6 & 287.2 & -0.8 \\
\hline \multicolumn{9}{|c|}{ Southern array (Fig. 5) } \\
\hline NPBA & 279.7 & -1.1 & 275.5 & -1.0 & 279.2 & -1.4 & 282.3 & -0.9 \\
\hline SKYR & 279.9 & 0.1 & 275.7 & 0.2 & 279.0 & 0.4 & 282.9 & 0.3 \\
\hline PUNT & 279.6 & 0.0 & 275.5 & -0.2 & 279.8 & -0.5 & 283.8 & -0 \\
\hline
\end{tabular}

To extend this analysis, we calculate the seasonal variability in temperature and $\mathrm{RACMO} 2$ temperature bias for the stations presented in Fig. 4 (northern array) and Fig. 5 (southern array), which is presented in Table 3. Although minor model biases $(0-2 \mathrm{~K})$ exist for all stations and in all seasons, we find no consistent seasonal bias differences. One exception is BALM, where RACMO2 overestimates the annual temperature amplitude, with overestimated (1-2 K) summer and autumn temperatures.

Figure 6 shows the observed and simulated wind speed and direction at the same stations. At NPBA and SKYR, mean wind speeds are 5 and $2 \mathrm{~m} \mathrm{~s}^{-1}$, respectively. A strong seasonality in wind speed exists at these station locations, with stronger winds in winter. These seasonal cycles are well represented by RACMO2, although wind speeds are over- and underestimated at NPBA and SKYR, respectively. These discrepancies between model and observations are to be expected, since both stations are located in rough terrain (Schneider et al. 2003), where local topography may strongly alter wind speed near the surface. Wind speeds at PUNT are higher $\left(\sim 7 \mathrm{~m} \mathrm{~s}^{-1}\right)$, due to the absence of rough topography in that region. Wind direction is similar at all stations, showing quasi-continuous northwesterly winds throughout the year. Wind directions in RACMO2 are slightly too zonal (westerly) at these stations. This is presumably a result of our assumption that wind direction at $2 \mathrm{~m}$ is equivalent to that at $10 \mathrm{~m}$ above the surface; in reality, surface roughness creates friction and deflects the flow clockwise close to the surface.
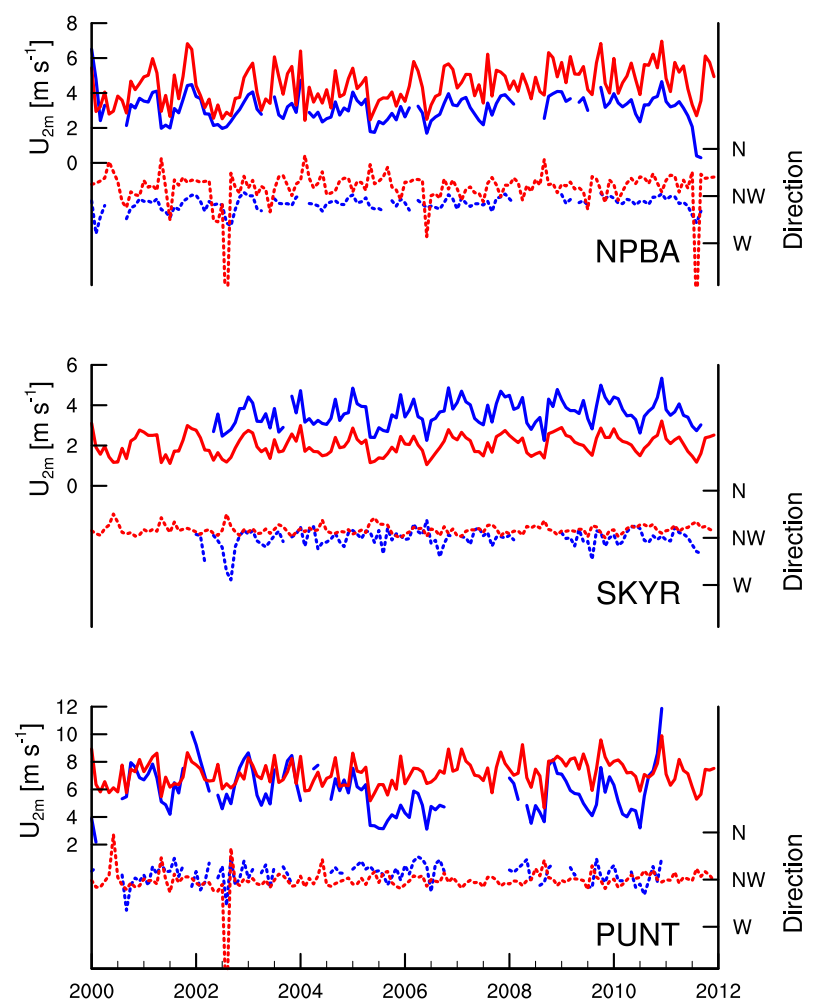

FIG. 6. Monthly mean wind speed (solid lines, left axis) and direction (dashed lines, right axis) from AWS observations (blue) at NPBA, SKYR, and PUNT (see Table 1) and from the closest grid point in RACMO2 (red) for the period 2000-11.

\section{c. Precipitation and accumulation}

The Andes range is oriented quasi-perpendicular to the orientation of the prevalent atmospheric flow, forming an efficient barrier enhancing the production of orographic precipitation. To quantify this effect, we use the so-called drying ratio, which is the ratio between the horizontal water vapor flux upstream and downstream of a mountain range. By measuring oxygen isotopic ratios in streamwater, Smith and Evans (2007) found that the drying ratio in the southern Andes (region of $40^{\circ}-48^{\circ} \mathrm{S}$ ) is exceptionally high $(\sim 0.56)$ compared to other mountain ranges of the world, such as the coastal mountains in Oregon (0.43) and the southern European Alps (0.35).

A latitude-time cross section of simulated drying ratio is depicted in Fig. 7. It clearly shows the strong latitudinal variations of drying ratio, with the highest $(>0.45)$ found across the ice fields $\left(47^{\circ}-51^{\circ} \mathrm{S}\right)$, where the maximum elevation is the highest. This suggests that the highest orographic precipitation is found on the ice fields, and supports the hypothesis that their existence is strongly related to high accumulation. Figure 7 also reveals a strong seasonal cycle in the drying ratio, with the lowest values in summer and a prolonged period of high 


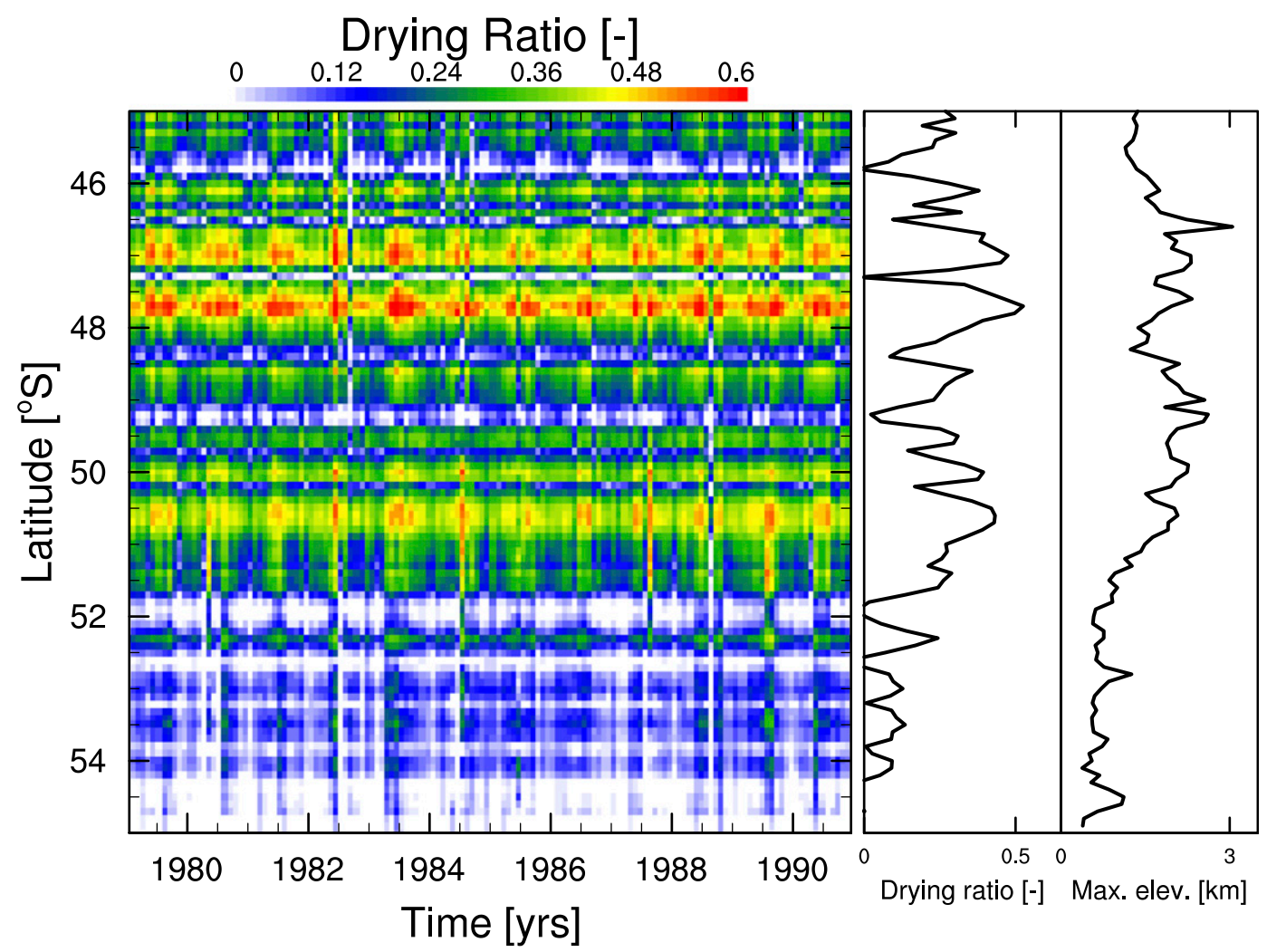

FIG. 7. (left) Temporal and latitudinal variations of modeled monthly drying ratio, defined as the RACMO2 monthly mean zonal water vapor flux ratio between $74^{\circ}$ and $70^{\circ} \mathrm{W}$ for the period $1979-90$. The water vapor flux is constructed following Smith and Evans (2007) and uses model output of specific humidity and winds at different pressure levels (surface and at 925, 850,700,500, and $300 \mathrm{hPa}$ ). (right) The time-averaged drying ratio and maximum elevation.

drying ratios during the rest of year, and large interannual variations (Fig. 7).

Figure $8 \mathrm{a}$ shows that modeled annual precipitation exceeds $5 \mathrm{~m}$ w.e. along the majority of the western flanks of the southern Andes. Largest amounts are found on the ice fields ( $>10 \mathrm{~m}$ w.e.), with up to $34 \mathrm{~m}$ w.e. at the southern end of the SPI $\left(51^{\circ} \mathrm{S}, 73^{\circ} 30^{\prime} \mathrm{W}\right)$ where the strongest upper-air wind field convergence is found (Fig. 2). East of the Andes, annual precipitation quickly drops to less than $1 \mathrm{~m}$ w.e., and less than $500 \mathrm{~mm}$ w.e. in the low-lying Argentinian steppe regions. Figure $8 \mathrm{~b}$ shows a more detailed picture of the sharp zonal precipitation gradient along the mountain range, particularly on the ice fields. Simulated precipitation is compared to available observations from weather stations (see Table 1), results of which are shown in Figs. $8 \mathrm{~b}$ and 9. Although relatively few observations are available, they broadly confirm the simulated gradients; stations located west of the divide receive more than $2 \mathrm{~m}$ w.e. of precipitation (green to red colors), whereas stations located east of the Andes are much drier (dark blue to light blue from west to east).
Local precipitation amounts strongly depend on the exact topography, which is not always resolved at a grid scale of $5.5 \mathrm{~km}$. Therefore, directly comparing simulated and locally observed precipitation is a stringent test for model performance, and needs to be interpreted with certain caution. Figure 9 supports the aforementioned sharp gradients in modeled precipitation from west to east. Stations RIPN-RIPA are coastal stations, where precipitation seasonality is limited and most precipitation falls in early winter. PASO and NPBA are located just west of the Andes crest and are the stations with the largest precipitation amounts $\left(5-7 \mathrm{~m}\right.$ w.e. $\left.\mathrm{yr}^{-1}\right)$. Interestingly, most precipitation here falls in summer, which was also reported by Garreaud et al. (2013), and seasonal variability is large. This is due to the strong episodic nature of extreme precipitation events, with reports of single days receiving several hundreds of $\mathrm{mm}$ of precipitation, mostly in summer (Schneider et al. 2003). Stations CHAC-AYSE are stations just east of the divide, with precipitation maxima in winter and annual amounts that depend on the exact location and neighboring topography. Finally, stations SKYR-CHIC 

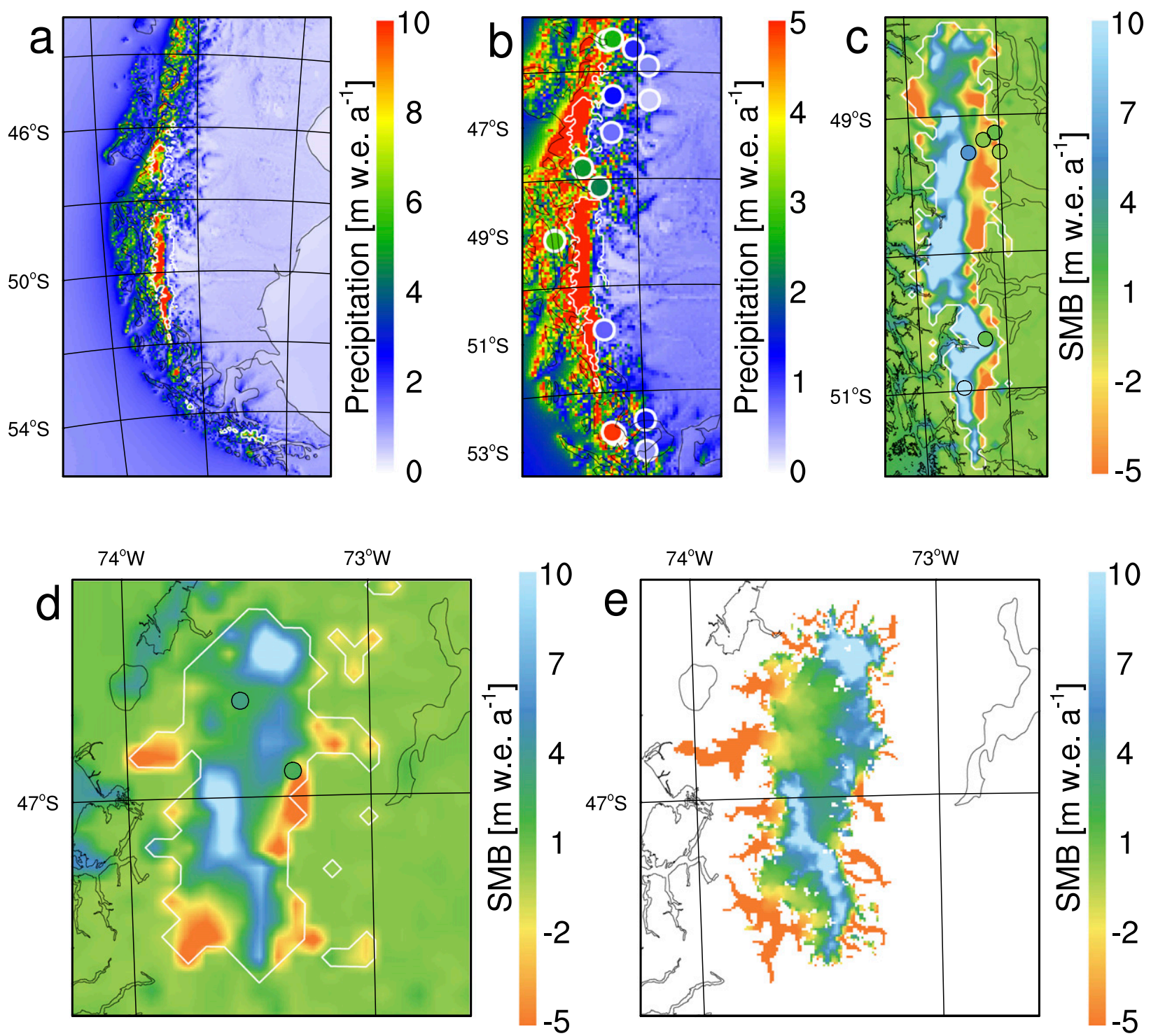

FIG. 8. Simulated annual mean precipitation for (a) the entire domain and (b) zoomed in on western Patagonia and SMB zoomed in on (c) SPI and (d) NPI. Available precipitation observations from weather stations [in (b); see Table 1] and SMB from firn cores [in (c) and (d); see Table 2] are included. The simulated fields are contoured with observations shown by colored circles using the same color scale as the model field. (e) The NPI calibrated SMB field (1975-2011) from Schaefer et al. (2013).

are located in drier regions east of the Andes, with much lower precipitation and small seasonal variability. RACMO2 is able to resolve the observed gradients, and the modeled precipitation generally agrees reasonably well with the observations (accounting for the large spatial variations and $\sim 20 \%$ uncertainty in the observations). The model somewhat underestimates the seasonal cycle in the observations at most stations, but generally captures the timing of the wettest month of the year reasonably well.

The main advantage of this high-resolution atmospheric product RACMO2 is the ability to reproduce the sharp topography and related orographic precipitation, a feature that is absent in state-of-the-art atmospheric reanalyses or general circulation models. Figure 10 shows that RACMO2 simulates much more precipitation in the coastal regions and west of the Andes, and better resolves the strong drying east of the Andes range, whereas ERA-Interim considerably smooths the precipitation field. As a reference, we also included ERA-Interim results in Fig. 9. Unlike RACMO2, ERAInterim is unable to reproduce the large precipitation gradients suggested by the observations; it clearly overestimates precipitation in the coastal regions, 


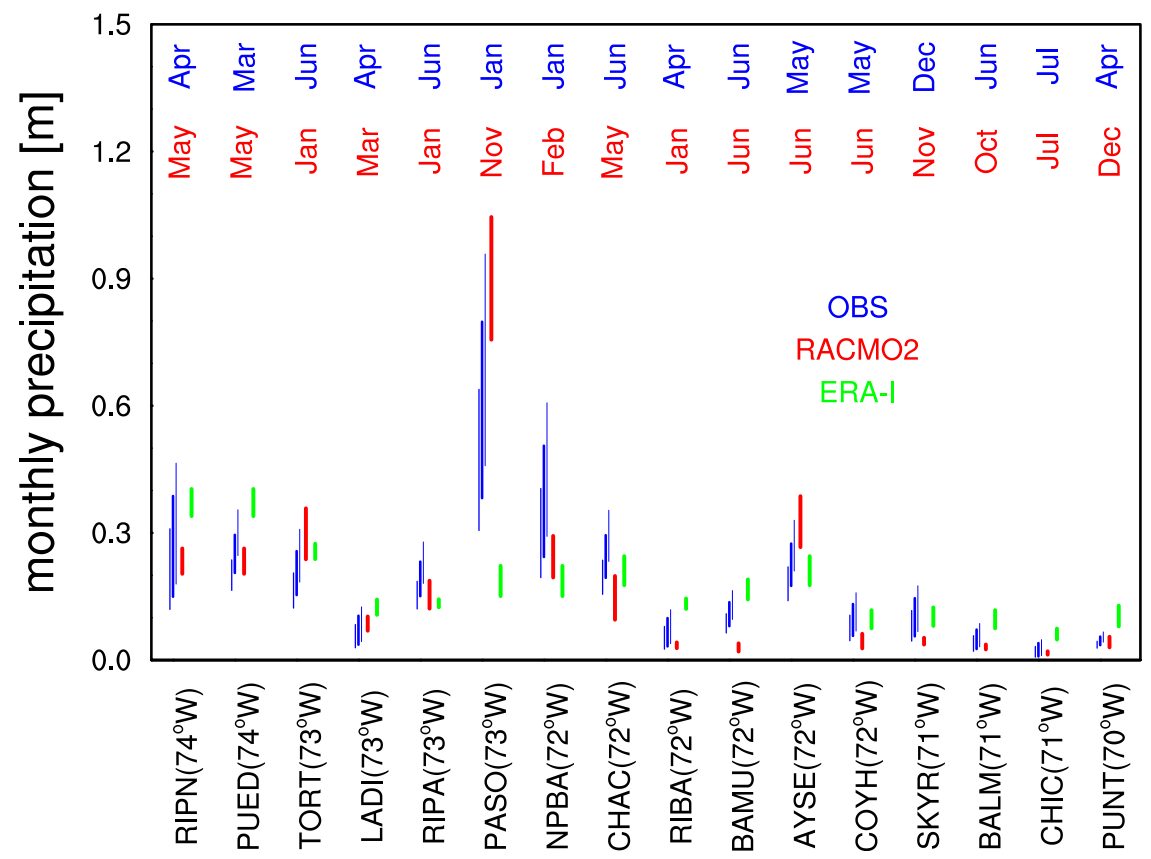

FIG. 9. Monthly accumulated precipitation at the weather stations that measured precipitation (blue; Table 1) and according to RACMO2 (red) and ERA-Interim (green) for the overlapping months (the observational period is different for each station). The vertical extent of the bars is a measure of the seasonal variability of precipitation and the month with the highest precipitation is shown above each station. The thin blue bars are the observed monthly precipitation including a $20 \%$ measurement error (see text). The stations are ordered from west (left) to east (right) with their approximate longitude $\left({ }^{\circ} \mathrm{W}\right)$ denoted on the horizontal axis.

underestimates orographic precipitation west of the Andes, and simulates too much precipitation at the stations located east of the Andes range.

Precipitation on the upper ice fields generally falls as snow, and at this elevation meltwater generally refreezes in the snowpack (Schwikowski et al. 2013). Therefore, the local firn acts as a robust "archiver" of past accumulation, particularly because annual layers can be easily detected given that the seasonal variability of temperature, and hence oxygen isotope ratio, is large (Schwikowski et al. 2013). Figure $8 c$ displays the annual mean simulated SMB on the NPI and SPI, along with available SMB observations from firn cores (Table 2). All cores are located in areas with extreme SMB gradients, and RACMO2 biases (Table 2) are related to the slight displaced location of this sharp gradient. Modeled SMB is very large $\left(>10 \mathrm{~m}\right.$ w.e. $\left.\mathrm{yr}^{-1}\right)$ on the western sides of the ice fields, but is largely negative on much of the eastern sides $(<2 \mathrm{~m}$ w.e. $\mathrm{yr}^{-1}$ ). This is related not only to less precipitation (Fig. 8b), but also to the strong surface melt and runoff that are driven by pronounced downward shortwave radiation (Fig. 3d) and the relatively low surface albedo in the lower ice-covered regions in summer $(<0.5$; Fig. $3 \mathrm{e})$.

RACMO2 is capable of resolving the high SMB (see Table 2) on San Rafael [3.3 m w.e. (RACMO2) vs
$3.5 \mathrm{~m}$ w.e. in the observations] on the NPI, and on Tyndall (13.7 vs $15.4 \mathrm{~m}$ w.e.) and Pio XI (6.1 vs $5.8 \mathrm{~m} \mathrm{w}$. e.) on the SPI. However, it fails to capture the high SMB on Nef glacier ( $-3.5 \mathrm{vs} 2.2 \mathrm{~m}$ w.e.) and the relatively low SMB on Moreno B (10.9 vs $1.2 \mathrm{~m}$ w.e.). These differences can probably be ascribed to a displaced location of the steep SMB gradient (Fig. 8c), elevation differences, and unresolved subgrid topography. The remaining observations originate from elevations close to the equilibrium line altitude, where meltwater is produced more abundantly and runs off, and SMB is very dependent on the exact altitude. Here, observations and RACMO2 agree on the near-zero SMB (within $\pm 1 \mathrm{~m} \mathrm{w}$. e.). Interestingly, RACMO2 also indicates that most firn core locations exhibit extremely large temporal SMB variability, with the interannual standard deviation in the same order of magnitude than the mean value (Table 2). This suggests that observations with a length of a single year or a few years may not be representative for the long-term SMB. This interannual variability is driven by large year-to-year variations in precipitation but is also due to variability in summer temperatures and subsequent melt. Model evaluation of SMB is extended through a direct comparison with the recently published, calibrated, high-resolution SMB on NPI 

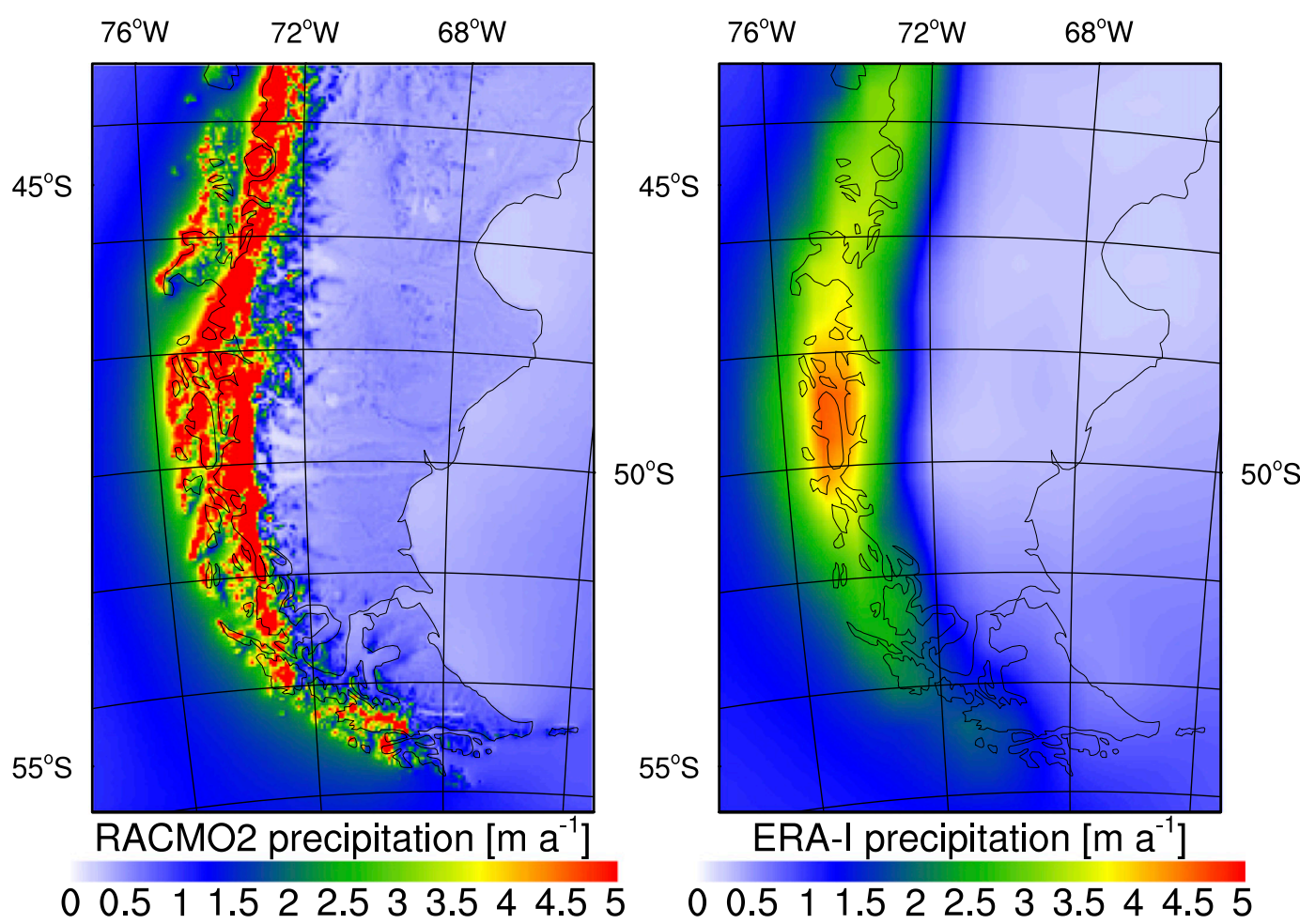

FIG. 10. Annual mean precipitation in (left) RACMO2 and (right) ERA-Interim (1979-2012).

(Schaefer et al. 2013), which is illustrated in Figs. 8d and 8e. Despite its coarser resolution $(5.5 \mathrm{~km}$ vs $450 \mathrm{~m})$ and different period (1979-2012 vs 1975-2011), RACMO2 simulates a mean SMB that compares well to the calibrated field. The two SMB maxima ( $>10 \mathrm{~m}$ w.e.) collocate, with high SMB along the southern ridge and in the northern NPI, where elevation is highest $(\sim 3000 \mathrm{~m}$ MSL; see Fig. 7). Although the outlet glaciers are not resolved in the glacier mask, RACMO2 simulates realistic locations and magnitudes of ablation in the lowlying regions.

\section{d. Recent trends}

With our long-term (34 yr) and continuous RACMO2 dataset, we are able to analyze the recent climate trends that have occurred in Patagonia. This allows us to potentially attribute recent ice field mass losses to atmospheric processes, such as decreasing precipitation or increased runoff. Figures $11 \mathrm{a}$ and $11 \mathrm{~b}$ give the best linear trend in temperature at $700 \mathrm{hPa}$ (closest pressure level to the elevation of the upper accumulation zones of the ice fields) and precipitation, respectively. RACMO2 suggests a highly significant decrease in temperature, in particular in western Patagonia (from -0.005 to $-0.01 \mathrm{~K} \mathrm{yr}^{-1}$ ). Trends in precipitation are less significant, although there are some hints toward increasing precipitation in the region of the ice fields (Fig. 11b).
For both NPI and SPI, we find large interannual variability of SMB (Fig. 11c), with high temporal correlation between both ice fields. This is related to the high interannual variability in atmospheric transport of moisture, driving the orographic precipitation (and drying ratio; see Fig. 7). On top of this interannual variability, we find a weak positive trend in SMB, which is marginally significant for NPI $(0.09 \pm$ $\left.0.05 \mathrm{Gt} \mathrm{yr}^{-2}\right)$, but not for SPI $\left(0.46 \pm 0.91 \mathrm{Gt} \mathrm{yr}^{-2}\right)$, equivalent to a relative SMB increase of $1.0 \pm 0.6 \%$ $\mathrm{yr}^{-1}$ for NPI and $0.8 \pm 1.6 \% \mathrm{yr}^{-1}$ for SPI, respectively. This increase in SMB is primarily driven by a decrease in surface runoff (caused by decreased atmospheric temperatures), and to a lesser extent by an increase in precipitation (not shown).

\section{Discussion and conclusions}

High-resolution regional climate model output is used to describe the present-day climate of Patagonia. The narrow Andes mountain range forms a sharp topographical barrier that separates regions to the west, with a very wet climate, from regions to the east with much less precipitation, stronger near-surface winds, and colder winters. Orographic uplift and precipitation generation is an efficient process in the southern Andes. The resulting large climate gradients are captured by RACMO2, such 

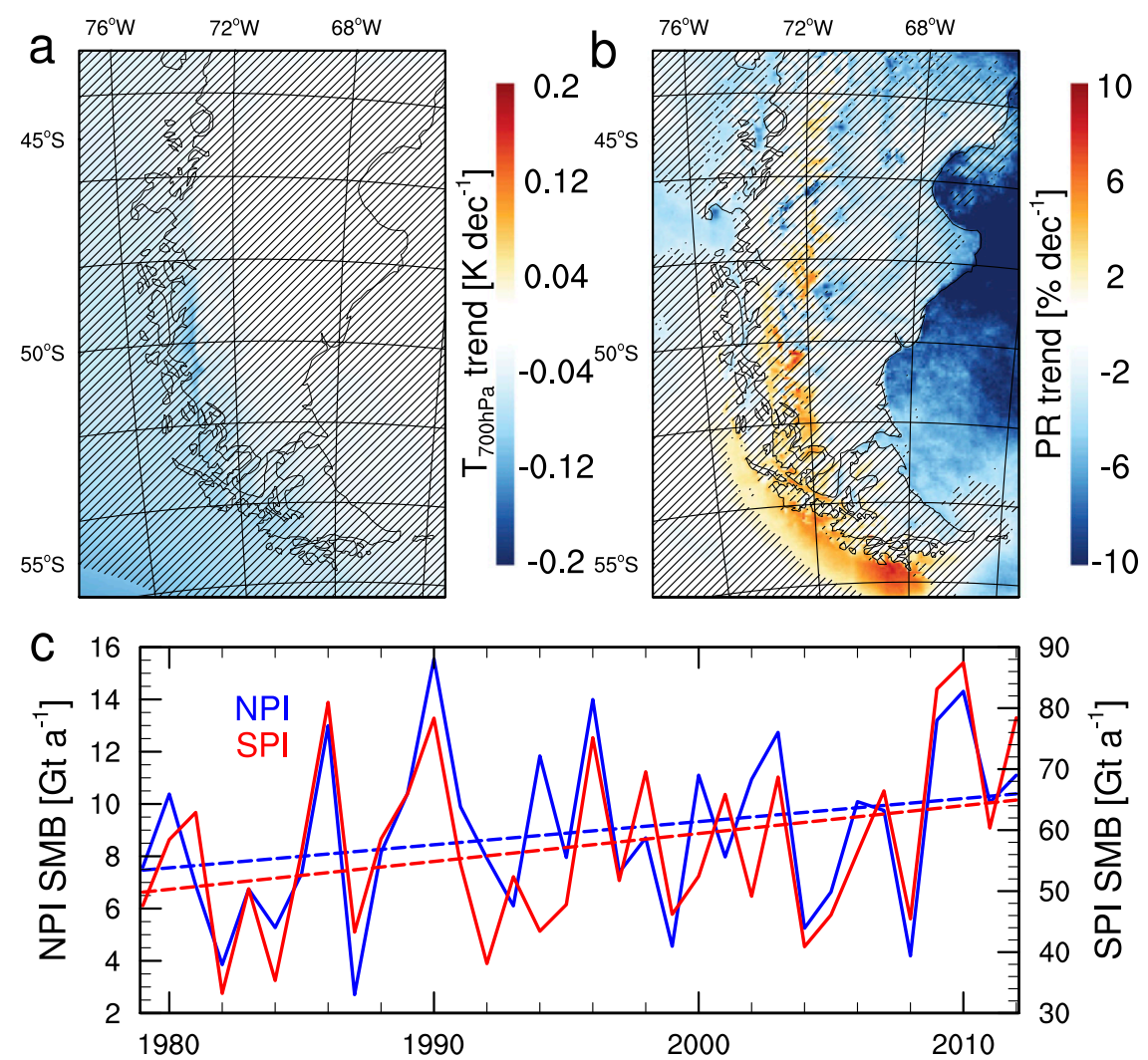

FIG. 11. Linear trend in 700-hPa (a) temperature and (b) precipitation based on monthly RACMO2 data (1979-2012). The linear trend is significant at the $90 \%$ level in nondashed areas. (c) Time series of annual area-integrated SMB of the NPI (blue) and SPI (red) with the linear trend shown by the dashed lines.

as the clear rain shadow and warm, dry, downslope (foehn) winds on the eastern side. The maximum amounts of annual precipitation simulated by RACMO2 are extremely high (10-30 m w.e. $\left.\mathrm{yr}^{-1}\right)$ and, if realistic, may represent the highest precipitation values on earth. A high-resolution model is necessary to adequately resolve orographic precipitation effects. Well-known reanalysis products such as ERA-Interim (Fig. 10) considerably smooth the orographic precipitation gradient. Evaluating the simulated amounts of precipitation remains challenging in the absence of reliable observations, but, qualitatively, RACMO2 is able to resolve the sharp zonal climate gradients, and the modeled high snowfall on the ice fields is broadly confirmed by firn cores. Moreover, equivalent amounts were simulated by the Weather Research and Forecasting (WRF) model at the same horizontal resolution on the NPI (Schaefer et al. 2013; Villarroel et al. 2013), with very similar spatial patterns. Using a linear precipitation model, highresolution terrain information, and observed oxygen isotope ratios, Smith and Evans (2007) predicted similarly high spatial variability in the region $44^{\circ}-46^{\circ} \mathrm{S}$, with strong dependency on the orientation of the local topography. On the most exposed north-south-oriented mountains, they obtained localized patches with $40 \mathrm{~m}$ w.e. of precipitation. RACMO2 compares reasonably well with the regional patterns of precipitation (Smith and Evans 2007) and we thus believe that the simulated precipitation amounts are potentially realistic.

Our model results suggest annual precipitation of $\sim 30 \mathrm{Gt} \mathrm{yr}^{-1}$ on the NPI and $\sim 120 \mathrm{Gt} \mathrm{yr}^{-1}$ on the SPI. If so, and with an estimated NPI total calving of $\sim 3 \mathrm{Gt} \mathrm{yr}^{-1}$ (Schaefer et al. 2013), this would imply that at least $\sim 27 \mathrm{Gt} \mathrm{yr}^{-1}$ is lost through surface melt and subsequent runoff on NPI only. Unfortunately, our model only partly resolves the glacier tongues, which are usually only a few $\mathrm{km}$ wide (see, e.g., Fig. 1). As a result, surface runoff is underestimated and SMB of the low-lying glacier parts is overestimated ( $\sim 8 \mathrm{Gt} \mathrm{yr}^{-1}$; Fig. 11$)$. A forthcoming study will improve the SMB estimates by statistically downscaling the simulated SMB toward a high-resolution ice mask and elevation model (Helsen et al. 2012).

Finally, our results suggest a small increase of SMB, mainly on NPI, in the period 1979-2012. This is 
primarily driven by decreasing upper-atmospheric temperatures, decreasing surface melt, and runoff. The recent ice losses from the NPI and SPI, and their relatively short response times to climate perturbations (Casassa et al. 1997), suggest that the slight cooling reported here is dominated by the long-term atmospheric warming since the early twentieth century (Rosenblüth et al. 1997). Moreover, it remains unclear whether these decreasing temperature trends are real or related to data inhomogeneities in the driving atmospheric reanalyses; for example, although National Centers for Environmental Prediction (NCEP) reanalysis suggests that a long-term warming of $\sim 0.5 \mathrm{~K}$ occurred at $850 \mathrm{hPa}$ in the period 1960-2000, a slight cooling in the 1990s compared to the 1980s was found (Rasmussen et al. 2007). These small cooling trends are confirmed by ERA-Interim at 850 and $700 \mathrm{hPa}$ (not shown) and also by satellite observations (Vose et al. 2012), but cannot be validated due to the lack of upper-air (radiosonde) observations or mountain station observations (Rasmussen et al. 2007). In general, we find that the signal of temporal variability of temperature and precipitation from year to year dominates that of a possible long-term trend in the period 1979-2012.

Acknowledgments. The authors are grateful to the Chilean Water Directory (DGA) and the Chilean Weather Service (DMC), and to Christoph Schneider (RWTH Aachen University) and Nicolas Butorovic (Laboratorio de climatologia, Instituto de la Patagonia, Universidad de Magallanes) for sharing their weather station data. We thank three anonymous reviewers and editor P. Clark for their constructive comments.

\section{REFERENCES}

Aristarain, A. J., and R. J. Delmas, 1993: Firn-core study from the southern Patagonia ice cap, South America. J. Glaciol., 39, 249-254.

Beljaars, A. C. M., A. R. Brown, and N. Wood, 2004: A new parametrization of turbulent orographic form drag. Quart. J. Roy. Meteor. Soc., 130, 1327-1347, doi:10.1256/qj.03.73.

Casassa, G., H. Brecher, and A. Rivera, 1997: A century-long recession record of Glaciar O'Higgins, Chilean Patagonia. Ann. Glaciol., 24, 106-110.

Champeaux, J. L., V. Masson, and F. Chauvin, 2005: ECOCLIMAP: A global database of land surface parameters at $1 \mathrm{~km}$ resolution. Meteor. Appl., 12, 29-32, doi:10.1017/S1350482705001519.

Chen, J. L., C. R. Wilson, B. D. Tapley, D. D. Blankenship, and E. R. Ivins, 2007: Patagonia Icefield melting observed by Gravity Recovery and Climate Experiment (GRACE). Geophys. Res. Lett., 34, L22501, doi:10.1029/2007GL031871.

Dee, D. P., and Coauthors, 2011: The ERA-Interim reanalysis: Configuration and performance of the data assimilation system. Quart. J. Roy. Meteor. Soc., 137, 553-597, doi:10.1002/qj.828.
ECMWF-IFS, 2008: IFS Documentation-CY33R1. Part IV: Physical Processes. ECMWF, 162 pp. [Available online at http://www.ecmwf.int/research/ifsdocs/CY33r1/PHYSICS/ IFSPart4.pdf.]

Escobar, F., V. Fernando, and C. Garin, 1992: Water balance in the Patagonia icefield. Glaciological Researches in Patagonia, 1990, R. Naruse and M. Aniya, Eds., Japanese Society of Snow and Ice, 109-119.

Ettema, J., M. R. van den Broeke, E. van Meijgaard, W. J. van de Berg, J. E. Box, and K. Steffen, 2010: Climate of the Greenland ice sheet using a high-resolution climate model-Part 1: Evaluation. Cryosphere, 4, 511-527, doi:10.5194/tc-4-511-2010.

Gardner, A. S., and Coauthors, 2013: A reconciled estimate of glacier contributions to sea level rise: 2003 to 2009. Science, 340, 852-857, doi:10.1126/science.1234532.

Garreaud, R., P. Lopez, M. Minvielle, and M. Rojas, 2013: Largescale control on the Patagonian climate. J. Climate, 26, 215230, doi:10.1175/JCLI-D-12-00001.1.

Glasser, N. F., S. Harrison, K. N. Jansson, K. Anderson, and A. Cowley, 2011: Global sea-level contribution from the Patagonian Icefields since the Little Ice Age maximum. Nat. Geosci., 4, 303-307, doi:10.1038/ngeo1122.

Helsen, M. M., R. S. W. van de Wal, M. R. van den Broeke, W. J. van de Berg, and J. Oerlemans, 2012: Coupling of climate models and ice sheet models by surface mass balance gradients: Application to the Greenland Ice Sheet. Cryosphere, 6, 255-272, doi:10.5194/tc-6-255-2012.

Hobbs, J. E., J. Lindesay, and H. A. Bridgman, 1998: Climates of the Southern Continents: Present, Past, and Future. Wiley, 297 pp.

Huffman, G. J., R. F. Adler, D. T. Bolvin, and G. Gu, 2009: Improving the global precipitation record: GPCP version 2.1. Geophys. Res. Lett., 36, L17808, doi:10.1029/2009GL040000.

Kuipers Munneke, P., M. R. van den Broeke, J. T. M. Lenaerts, M. G. Flanner, A. Gardner, and W. J. van de Berg, 2011: A new albedo scheme for use in climate models over the Antarctic ice sheet. J. Geophys. Res., 116, D05114, doi:10.1029/ 2010JD015113.

Lenaerts, J. T. M., and M. R. van den Broeke, 2012: Modeling drifting snow in Antarctica with a regional climate model: 2. Results. J. Geophys. Res., 117, D05109, doi:10.1029/2010JD015419.

,$- \ldots$, S. J. Déry, E. van Meijgaard, W. J. van de Berg, S. P. Palm, and J. Sanz Rodrigo, 2012a: Modeling drifting snow in Antarctica with a regional climate model: 1 . Methods and model evaluation. J. Geophys. Res., 117, D05108, doi:10.1029/ 2011JD016145.

,-- , W. J. van de Berg, E. Van Meijgaard, and P. Kuipers Munneke, 2012b: A new, high-resolution surface mass balance map of Antarctica (1979-2010) based on regional atmospheric climate modeling. Geophys. Res. Lett., 39, L04501, doi:10.1029/2011GL050713.

_ J. H. van Angelen, M. R. van den Broeke, A. S. Gardner, B. Wouters, and E. van Meijgaard, 2013: Irreversible mass loss of Canadian Arctic Archipelago glaciers. Geophys. Res. Lett., 40, 870-874, doi:10.1002/grl.50214.

Mass, C. F., D. Ovens, K. Westrick, and B. A. Colle, 2002: Does increasing horizontal resolution produce more skillful forecasts? Bull. Amer. Meteor. Soc., 83, 407-430, doi:10.1175/ 1520-0477(2002)083<0407:DIHRPM > 2.3.CO;2.

Matsuoka, K., and R. Naruse, 1999: Mass balance features derived from a firn core at Hielo Patagonico Norte, South America. Arct. Antarct. Alp. Res., 31, 333-340, doi:10.2307/1552582. 
Naruse, R., P. Skvarca, and Y. Takeuchi, 1997: Thinning and retreat of Glaciar Upsala, and an estimate of annual ablation changes in southern Patagonia. Ann. Glaciol., 24, 38-42.

Ohata, T., 1985: Heat balance at the snow surface in a katabatic wind zone, east Antarctica. Ann. Glaciol., 6, 174-177.

Popovnin, V. V., T. A. Danilova, and D. A. Petrakov, 1999: A pioneer mass balance estimate for a Patagonian glacier: Glaciar De los Tres, Argentina. Global Planet. Change, 22, 255-267, doi:10.1016/S0921-8181(99)00042-9.

Rasmussen, L. A., H. Conway, and C. F. Raymond, 2007: Influence of upper air conditions on the Patagonia icefields. Global Planet. Change, 59, 203-216, doi:10.1016/j.gloplacha.2006.11.025.

Reuter, H. I., A. Nelson, and A. Jarvis, 2007: An evaluation of voidfilling interpolation methods for SRTM data. Int. J. Geogr Inf. Sci., 21, 983-1008, doi:10.1080/13658810601169899.

Rignot, E., A. Rivera, and G. Casassa, 2003: Contribution of the Patagonia Icefields of South America to sea level rise. Science, 302, 434-437, doi:10.1126/science.1087393.

Rivera, A., 2004: Mass balance investigations at Glaciar Chico, Southern Patagonia Icefield, Chile. Ph.D. thesis, University of Bristol, 303 pp.

—_, C. Acuña, G. Casassa, and F. Bown, 2002: Use of remotely sensed and field data to estimate the contribution of Chilean glaciers to eustatic sea-level rise. Ann. Glaciol., 34, 367-372, doi:10.3189/172756402781817734.

Rosenblüth, B., H. A. Fuenzalida, and P. Aceituno, 1997: Recent temperature variations in southern South America. Int. J. Climatol., 17, 67-85, doi:10.1002/(SICI)1097-0088(199701)17:1<67:: AID-JOC120>3.0.CO;2-G.

Schaefer, M., H. Machguth, M. Falvey, and G. Casassa, 2013: Modeling past and future surface mass balance of the Northern Patagonia Icefield. J. Geophys. Res. Earth Surf., 118, 571588, doi:10.1002/jgrf.20038.

Schneider, C., M. Glaser, R. Kilian, A. Santana, N. Butorovic, and G. Casassa, 2003: Weather observations across the southern Andes at $53^{\circ}$ S. Phys. Geogr., 24, 97-119, doi:10.2747/ 0272-3646.24.2.97.

Schwikowski, M., S. Brütsch, G. Casassa, and A. Rivera, 2003: First shallow firn core record from Gorra Blanca, Patagonia. Geophysical Research Abstracts, Vol. 5, Abstract 01427.

_ - M. Schläppi, P. Santibañez, A. Rivera, and G. Casassa, 2013: Net accumulation rates derived from ice core stable isotope records of Pío XI glacier, Southern Patagonia Icefield. Cryosphere, 7, 1635-1644, doi:10.5194/tc-7-1635-2013.
Shiraiwa, T., S. Kohshima, R. Uemura, N. Yoshida, S. Matoba, J. Uetake, and M. A. Godoi, 2002: High net accumulation rates at Campo de Hielo Patagónico Sur, South America, revealed by analysis of a $45.97 \mathrm{~m}$ long ice core. Ann. Glaciol., 35, 84-90, doi:10.3189/172756402781816942.

Smith, R. B., and J. P. Evans, 2007: Orographic precipitation and water vapor fractionation over the southern Andes. J. Hydrometeor., 8, 3-19, doi:10.1175/JHM555.1.

Trenberth, K. E., 1991: Storm tracks in the Southern Hemisphere. J. Atmos. Sci., 48, 2159-2178, doi:10.1175/ 1520-0469(1991)048<2159:STITSH > 2.0.CO;2.

Van Angelen, J. H., J. T. M. Lenaerts, S. Lhermitte, X. Fettweis, P. Kuipers Munneke, M. R. van den Broeke, E. van Meijgaard, and C. J. P. P. Smeets, 2012: Sensitivity of Greenland ice sheet surface mass balance to surface albedo parameterization: A study with a regional climate model. Cryosphere, 6, 1175-1186, doi:10.5194/tc-6-1175-2012.

Van Wessem, J. M., C. H. Reijmer, J. T. M. Lenaerts, W. J. van de Berg, M. R. van den Broeke, and E. van Meijgaard, 2014: Updated cloud physics in a regional atmospheric climate model improves the modelled surface energy balance of Antarctica. Cryosphere, 8, 125-135, doi:10.5194/ tc-8-125-2014.

Villarroel, C., J. Carrasco, G. Casassa, and M. Falvey, 2013: Modeling near-surface air temperature and precipitation using WRF with $5-\mathrm{km}$ resolution in the Northern Patagonia Icefield: A pilot simulation. Int. J. Geosci., 4, 1193-1199, doi:10.4236/ijg.2013.48113.

Vose, R. S., and Coauthors, 2012: NOAA's merged land-ocean surface temperature analysis. Bull. Amer. Meteor. Soc., 93, 1677-1685, doi:10.1175/BAMS-D-11-00241.1.

Warren, C. R., and D. E. Sugden, 1993: The Patagonian Icefields: A glaciological review. Arct. Alp. Res., 25, 316-331, doi:10.2307/ 1551915.

White, P., Ed., 2001: IFS Documentation Cycle CY23R4-Part IV: Physical processes. ECMWF, 166 pp. [Available online at http:// www.ecmwf.int/research/ifsdocs_old/pdf_files/Physics.pdf.]

Willis, M. J., A. K. Melkonian, M. E. Pritchard, and A. Rivera, 2012: Ice loss from the Southern Patagonian Ice Field, South America, between 2000 and 2012. Geophys. Res. Lett., 39, L17501, doi:10.1029/2012GL053136.

Yamada, T., 1987: Glaciological characteristics revealed by $37.6-\mathrm{m}$ deep core drilled at the accumulation area of San Rafael Glacier, the Northern Patagonia Icefield. Bull. Glacier Res., 4, 59-67. 